\title{
珊瑚礁地形上直立式防浪堤越浪大水槽实验
}

\author{
陈松贵 ${ }^{1,2}$, 王泽明 ${ }^{1}$, 张弛 ${ }^{1}$, 陈汉宝 ${ }^{2}$, 郑金海 $^{1^{*}}$ \\ 1. 河海大学港口海岸与近海工程学院, 南京 210024; \\ 2. 交通运输部天津水运工程科学研究院, 天津 300456 \\ * 联系人, E-mail: jhzheng@hhu.edu.cn
}

2018-12-02 收稿, 2019-02-16 修回, 2019-02-18 接受, 2019-09-26 网络版发表

国家杰出青年科学基金(51425901)、中央级公益性科研院所基本科研业务费(TKS150101)、水沙科学与水灾害防治湖南省重点实验室开放基 金(2019SS01)和中国博士后科学基金(2017M613320)资助

摘要 通过大比尺波浪水槽实验, 对珊瑚礁地形上的直立式防浪堤越浪规律进行了研究. 采用弗劳德相似准则, 按 照1:15的模型比尺，研究了规则波在筑堤珊瑚礁上的传播过程，分析了波高、周期、礁坪水深和防浪堤与礁缘之 间距离对越浪量的影响. 结果表明随着波高和周期的增大, 越浪量明显增大; 随着礁坪水深的减少, 堤顶离水面的 距离增大, 越浪量明显减少; 大部分情况下, 随着距离增加, 越浪量减少, 但在周期超过 $13.56 \mathrm{~s}$ 时, 由于防浪堤堤前 隹水的影响, 越浪量随着距离的增加存在先减小再增加之后再减小的趋势. 进一步讨论了波陡和相对干舷高度对 无量纲越浪量的影响, 结果显示当波高相同时, 波陡越大, 波浪破碎越剧烈, 无量纲平均越浪量越小; 而在相同的波 况下，相对千舷高度越小，无量纲越浪量越大；基于实验数据拟合出考虑波周期、入射波高、礁坪水深和防波堤与 礁缘之间距离影响的珊瑚礁上直立式防浪堤越浪量估算公式. 基于实验数据拟合出考虑波周期、入射波高、礁坪 水深和防波堤与礁缘之间距离影响的珊瑚礁上直立式防浪堤越浪量估算公式.

关键词珊瑚礁, 大比尺波浪水槽, 直立堤, 越浪公式

珊瑚礁在我国南海分布广泛 ${ }^{[1]}$, 其大多为自深水 (1000 m以上)中凸出的环礁，出水的礁盘水深很浅，同 时岛礁前坡常为 $1: 10 \sim 1: 0.5$ 的陡坡. 与沿海大陆架的缓 坡地形不同，陡变地形对波浪的传播和变形产生了巨 大的影响, 同时珊瑚礁所处的海洋环境复杂, 其水深面 宽、热带气旋活跃、季风盛行，并时常受到畸形波、 台风浪、风暴潮浪等极端波浪作用，这会严重影响到 回填砂岛的稳定性和其他附属设施的有效运行. 在珊 瑚礁地形的防护工程中防浪堤是重要防护建筑物, 防 浪堤在极端条件下不可避免地会发生越浪，所以防浪 堤越浪量的大小对珊瑚礁上的工程安全起到了决定性 的作用.

近些年国内外针对珊瑚礁海岸波浪水流的运动特
性开展了大量的研究. Gourlay等人 ${ }^{[2 \sim 4]}$ 对珊瑚礁地形上 不同的平均水位和人射波高引起的波浪增水及波生流 进行了一系列的实验, 研究发现当平均水位远高于礁 坪时, 珊瑚礁水动力主要受礁坪的底摩阻控制; 当平均 水位等于或低于礁盘平台时, 珊瑚礁水动力主要受礁 缘破碎波浪的控制. Jensen等人 ${ }^{[5]}$ 通过实验研究了规则 波和不规则波在前礁为陡坡的珊瑚礁地形上波浪的破 碎和波能的衰减，发现波能主要与波高、周期和礁坪 水深密切相关，并且给出了波高在陡坡珊瑚礁上的衰 减公式. Nwogu和Demirbilek ${ }^{[6]}$ 进行了不规则波在珊瑚 礁上的运动变化和礁后斜坡波浪爬高的物理模型实验, 发现大部分波能在人射波的几个波长内破碎而消散掉, 礁坪和后滩上的流体运动主要受到长周期振荡的控制, 
而振动会在礁坪上引起共振，导致波浪的爬高增加。 Fang $^{[7]}$ 在二维非线性Boussinesq方程的基础上利用激波 捕捉法对珊瑚礁海岸上的孤立波传播进行了数值模拟, 数值计算结果与物理模型实验数据符合度较好, 证明 了模型在处理波浪传播的非线性、色散效应、波浪破 碎和锋面的干湿移动等复杂流体动力学时的准确性. 姚宇等人 ${ }^{[8,9]}$ 采用物理模型实验研究了礁冠的存在和不 同的礁冠宽度对波浪传播变形和礁坪上增水的影响, 发现礁冠能显著改变波浪在礁坪边缘的传播变形过程, 而且礁冠宽度越大，波浪破碎造成的能量衰减越剧烈， 但是只有在礁冠充分宽的情况下礁冠水深才是控制礁 坪上增水的主要因素. 陈松贵等人 ${ }^{[10]}$ 研究了不规则波 在建有防浪堤的珊瑚礁陡变地形上传播变形规律, 结 果表明波浪在陡变地形上的浅水变形系数与缓坡地形 差别较大, 且在一定范围内随相对水深的减小而减小. 上述珊瑚礁研究中, 除了陈松贵等人 ${ }^{[10]}$ 以外, 其他研究 主要侧重于自然状态下外海人射波波浪在礁缘的破碎 特性以及在礁坪上的传播规律，均未考虑珊瑚礁上防 浪建筑物建设后对破碎波浪传播的阻碍作用，因为筑 堤后的珊瑚礁礁坪面积往往较小，建筑物的阻水效应 会显著影响珊瑚礁的波浪破碎等情况，所以还需对筑 堤珊瑚礁上的水动力特性进行深人研究.

国内外科研人员针对海岸工程中防浪堤的越浪规 律开展了大量的研究工作, 尤其是缓坡地形上防浪堤 的平均越浪量估算，不同国家的规范中均有各自的计 算公式. 我国《港口与航道水文规范》 ${ }^{[11]}$ 中采用的公 式是基于王红等人 ${ }^{[12,13]}$ 的研究成果. 俞聿修等人 ${ }^{[14,15]}$ 针 对不规则波在无胸墙斜坡堤和直立堤上的越浪情况， 进行了物理模型实验研究并提出了相应的越浪量计算 公式. 英国海岸工程设计手册中采用了Owen等人 ${ }^{[16 ~ 18]}$ 的研究成果，其公式考虑了单坡式和复合式斜坡堤两 种不同情况. Van der Meer等人 ${ }^{[19-22]}$ 对斜坡堤越浪进行 了系统的实验，所提出的越浪爬高公式和平均越浪量 公式被欧洲许多国家采用. 日本学者 $\mathrm{Goda}^{[23]}$ 对不规波 越浪进行了一系列实验研究, 其所著《港工建筑物的 防浪设计》中的越浪量公式被日本设计人员所使用. 美国《海岸工程手册》中的越浪量公式采纳了Ward和 Ahrens ${ }^{[24]}$ 的实验研究成果. 俞聿修等人 ${ }^{[25]}$ 对多种计算 平均越浪量的方法进行了分析比较, 并针对不同情况 提出各种计算方法的适用性. 这些研究成果已在近岸 防浪堤的越浪量计算中得到了很好的应用，但珊瑚礁 地形的防浪堤所处的地理环境与近岸缓坡地形截然不
同，建筑物前水深与波高的关系、底坡坡度等均不满 足缓坡地形上防浪堤越浪量计算公式的适用条件，而 且国内外针对筑堤珊瑚礁的越浪规律研究很少, 亟需 对珊瑚礁陡变地形上的防浪堤越浪规律开展系统的 研究.

\section{1 影响越浪的因素}

在我国的《港口与航道水文规范》 ${ }^{[11]}$ 中，有胸墙 时的斜坡堤单位时间单位堤宽越浪量 $(Q)$ 计算公式为

$$
\begin{gathered}
Q=0.07^{H_{\mathrm{c}}^{\prime} / H_{1 / 3}} \exp \left(0.5-\frac{b_{1}}{2 H_{1 / 3}}\right) B K_{\mathrm{A}} \frac{H_{1 / 3}^{2}}{T_{\mathrm{P}}} \\
{\left[\frac{0.3}{\sqrt{m}}+\operatorname{th}\left(\frac{d}{H_{1 / 3}}-2.8\right)^{2}\right] \ln \sqrt{\frac{g T_{\mathrm{P}}^{2} m}{2 \pi H_{1 / 3}}},}
\end{gathered}
$$

式中, $H_{\mathrm{c}}{ }^{\prime}$ 为胸墙墙顶在静水面以上的高度; $H_{1 / 3}$ 为有效 波高; $T_{\mathrm{p}}$ 为谱峰周期; $b_{1}$ 为胸墙前肩宽; $B$ 为与坡度有关 的经验系数; $K_{\mathrm{A}}$ 为护面结构的影响系数; $m$ 为斜坡坡度; $d$ 为建筑物前水深; $g$ 为重力加速度.

在国外的EurOtop (欧洲越浪规范) ${ }^{[26]}$ 中Van der Meer和Bruce ${ }^{[27]}$ 重新研究了 20 世纪70年代早期荷兰的 越浪实验工作，推出了适用于带胸墙的斜坡式防浪堤 的越浪计算公式:

$q=\frac{Q}{\sqrt{g H_{\mathrm{i}}^{3}}}=a \exp \left[-b \frac{R_{\mathrm{c}}}{H_{\mathrm{i}}}\right]$, 其中 $R_{\mathrm{c}}>0$,

式中, $H_{\mathrm{i}}$ 为人射波波高； $R_{\mathrm{c}} / H_{\mathrm{i}}$ 为相对干舷高度； $Q / \sqrt{g H_{\mathrm{i}}^{3}}$ 为无量纲平均越浪量 $(q) ; a$ 和 $b$ 为修正系数. 式(2)中对于越浪量大小的决定性影响因素是人射波波 高和干舷高度，利用修正系数 $a$ 和 $b$ 考虑了护岸结构、 坡面坡度、坡面䊁率、波浪破碎形式、波向、波周期 和护岸结构的距离这些影响越浪量的其他因素.

可以看出在缓坡地形上，国内外适用于带胸墙的 斜坡式防浪堤的越浪量公式中，越浪量的大小主要受 人射波波高、波周期、堤前水深的影响，但是在珊瑚 礁陡变地形上，除上述的3个影响因素外，越浪量的大 小还受到防浪堤与礁缘之间距离的不同和礁前斜坡坡 度的不同的影响，本实验主要探讨人射波波高、波周 期、堤前水深和防浪堤与礁缘之间距离这 4 个主要因 素对珊瑚礁上直立堤的越浪量的影响.

\section{2 实验设置}

为了更好地复原波浪从深水区传播至礁盘浅水区 
的复杂过程, 在交通运输部天津水运工程科学研究院 大比尺波浪水槽中完成实验研究，该水槽目前为世界 最大, 水槽长 $456 \mathrm{~m}$, 宽 $5 \mathrm{~m}$, 高 $12 \mathrm{~m}$. 在水槽一端为推 板式造波机, 最大造波能力为 $3.5 \mathrm{~m}$, 造波周期为 $2 \sim 10 \mathrm{~s}$. 实验采用弗劳德相似准则, 按 $1: 15$ 的模型比尺进行设 计，模型布置图如图1所示，主要包括深水区、陡坡区 和平台区3部分，陡坡区的坡度设计值参考Gourlay ${ }^{[4]}$ 关 于珊瑚礁坡度研究中的模型D(Reefs in Malé, Madldives), 陡坡坡脚距造波机距离 $330 \mathrm{~m}$, 其中深水区水深 $5 \mathrm{~m}$, 前坡分 3 段, 坡度分别为 $1: 1,1: 4$ 和 $1: 15$, 平台上设 有直立式防浪堤, 堤顶高 $0.6 \mathrm{~m}$, 顶宽 $0.15 \mathrm{~m}$, 底宽 $0.9 \mathrm{~m}$. 模型设置能够较好地模拟波浪从外海的深水区经过珊 瑚礁陡变地形变形破碎, 再至礁坪上传播的强非线性 物理过程.

实验斜坡和平台采用方钢管和钢板分段焊接而成, 实验平台上铺有 $10 \mathrm{~cm}$ 厚的混凝土以保持平台高程一 致，并且在钢板和水槽壁间隙采用混凝土闭合以防止 出现透水现象(图2). 水槽墙壁上端固定有 6 个间隔 $5 \mathrm{~m}$ 的高速摄像机, 用来记录波浪在礁坪上的传播过程. 实
验时，在深水处布置2根波高传感器测量深水波高，量 程 $2 \mathrm{~m}$, 距水槽边壁 $2.5 \mathrm{~m}$, 距陡坡边缘 $50 \mathrm{~m}$, 采用 $\operatorname{Sun}^{[28]}$ 提出的人反射分离方法计算得到每组实验的人射波 (图3). 所有波高传感器均采用电容式波高传感器, 精度 为千分之一，所有波高传感器通过数据采集系统同步 测量, 采样频率 $50 \mathrm{~Hz}$. 自波浪到深水处的浪高仪时开 始采集, 为避免实验受到二次反射波的影响, 每组实验 波浪的采集时间为 30 个波，均在二次反射波到达前停 止采集.

实验中, 采用长 $2.5 \mathrm{~m}$ 、宽 $0.15 \mathrm{~m}$ 、高 $0.15 \mathrm{~m}$ 的集水 槽收集越过防浪堤的水体, 集水槽位于防浪堤中间, 在 堤后 $2 \mathrm{~m}$ 处固定放置长 $1 \mathrm{~m}$ 、宽 $1 \mathrm{~m}$ 、高 $0.5 \mathrm{~m}$ 的铁箱来 储存收集到的越浪, 越浪箱前端焊有铁板来防止周边 的越浪溅进箱子(图2). 在收集越浪时，采集位于 30 个 波值中间的 10 个稳定波越浪. 采用单宽平均越浪量来 描述越浪大小, 即:

$Q=\lambda^{3 / 2} \frac{Q_{\mathrm{m}}}{n d T}$,

式中, $Q$ 为单宽平均越浪量原型值; $Q_{\mathrm{m}}$ 为越浪量的模型

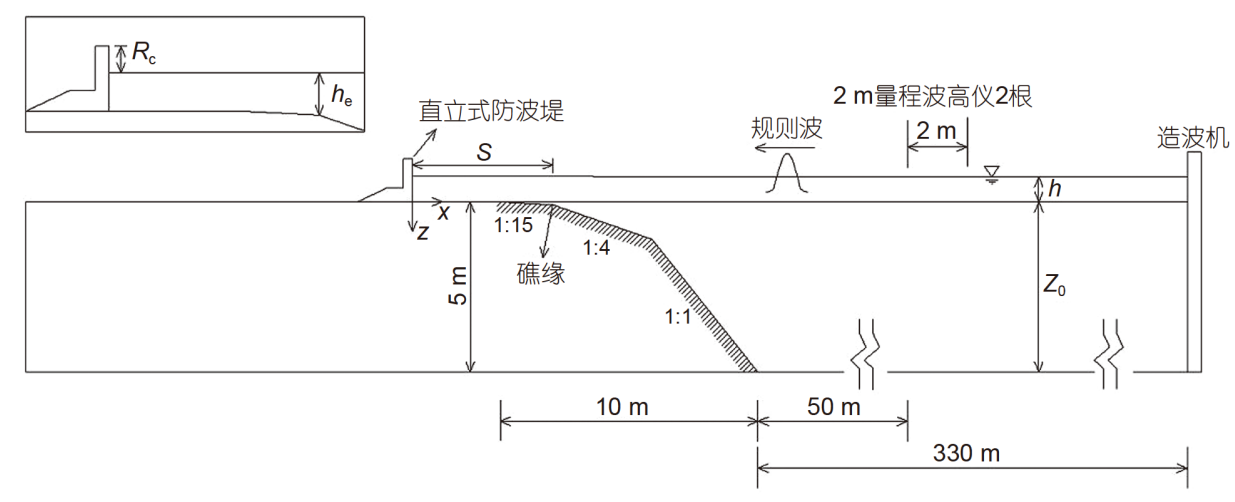

图 1 实验布置图

Figure 1 Experimental setup

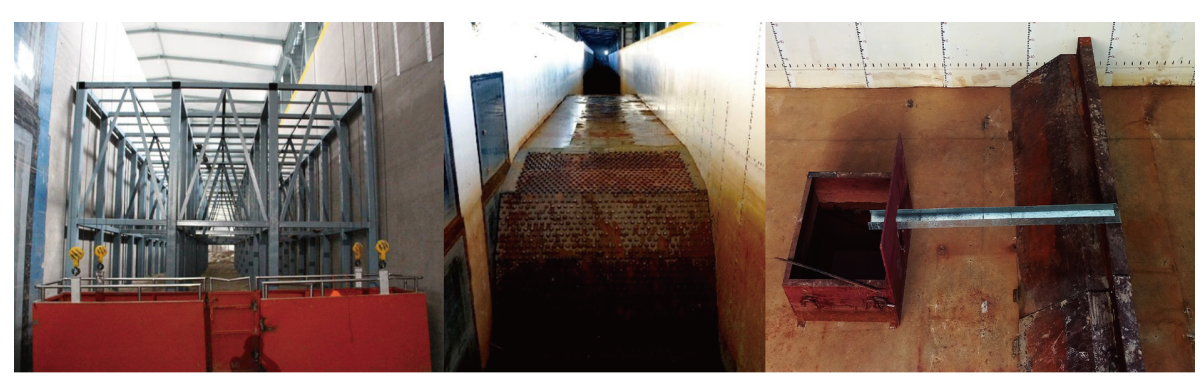

图 2 (网络版彩色)实验平台、防浪堤和接越浪装置

Figure 2 (Color online) Experimental platform, breakwater and device for collecting overtopping 

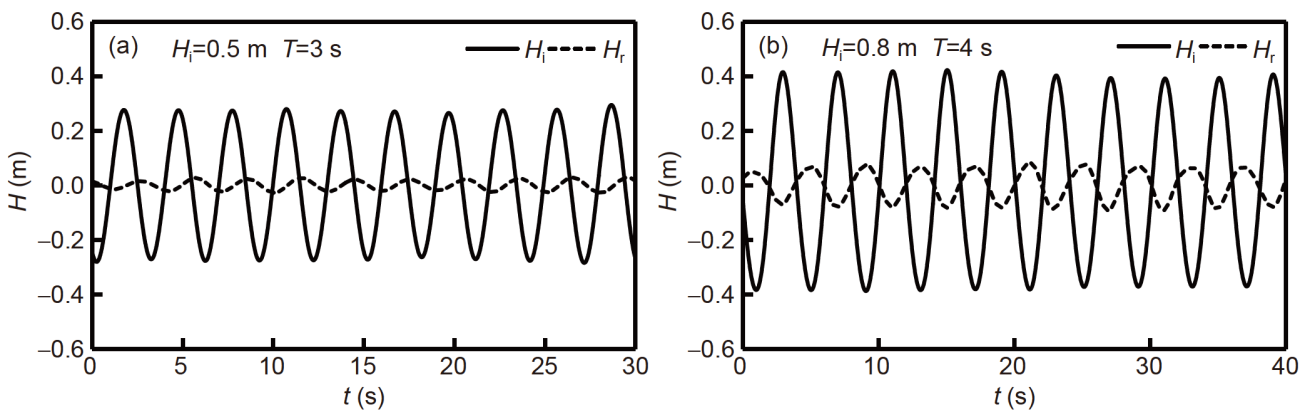

图 3 深水处人射波 $\left(H_{\mathrm{i}}\right.$ ) 和反射波 $\left(H_{\mathrm{r}}\right)$. (a) $H_{\mathrm{i}}=0.5 \mathrm{~m}, T=3 \mathrm{~s}$; (b) $H_{\mathrm{i}}=0.8 \mathrm{~m}, T=4 \mathrm{~s}$

Figure 3 The incident wave $\left(H_{\mathrm{i}}\right)$ and reflected wave $\left(H_{\mathrm{r}}\right)$ at deep water. (a) $H_{\mathrm{i}}=0.5 \mathrm{~m}, T=3 \mathrm{~s}$; (b) $H_{\mathrm{i}}=0.8 \mathrm{~m}, T=4 \mathrm{~s}$

值; $\lambda$ 为实验模型比尺(取 15$) ; n$ 为实验中越浪所采集的 波个数(取 10$) ; d$ 为集水槽的宽度(取 $0.15 \mathrm{~m}$ ); $T$ 为人射波 周期模型值.

实验组次共包含 3 个水位, 4 个周期, 6 个波高和 4 个 防浪堤与礁缘之间的间距(表1)，实验的原型值均能较 好地反映极端的波浪情况. 实验时人射波均采用规则 波，每种工况重复3次，单次间人射波波高和越浪量的 采集数据误差均小于 $5 \%$, 实验设备的重复性良好, 最终 结果为 3 次测量数据的平均值.

\section{3 实验结果与分析}

\section{1 波浪的沿程变化及越浪现象}

从实验中的高速摄像机视频记录可以看出，波浪 在珊瑚礁陡变地形上的传播规律与缓坡地形明显不同, 由于陡变地形上水深急剧减小, 并且礁坪上水深很浅, 波浪在礁缘附近直接发生破碎，之后以破碎波的形式 继续向防浪堤传播，由于防浪堤与礁缘之间的距离不 同，破碎波在礁坪上的传播过程也有所区别. 当实验中 人射波波陡较大时，波浪在礁缘处以卷破波的形式发
生破碎；当波陡小时，以激破波的形式破碎. 防浪堤离 礁缘很近，波浪在破碎过程中就已经到达了防浪堤处， 在防浪堤前产生隹水，破碎波越过防浪堤引起越浪同 时产生反射波，反射波在沿着远离防浪堤方向运动的 过程中在礁坪上与下一个人射波发生碰撞，人射波碰 撞结束后继续以破碎波的形式向防浪堤移动，再次发 生越浪并且产生反射波，如此循环(图4). 当防浪堤与 礁缘之间的距离增加时，人射波与反射波在礁坪上的 接触次数会增多, 人射波的能量随之耗散, 使到达防浪 堤时的波能逐渐减少，从而导致越浪量减小. 此外，同 时从实验现象中观察到，当防浪堤与礁缘之间的距离 一定时，人射波和反射波在礁坪上的接触次数会随着 周期的增加而减少.

\section{2 波高和周期对平均越浪量的影响}

如图 5 所示, 防浪堤距离礁缘为 $75 \mathrm{~m}$, 堤前水深为 3 和 $0 \mathrm{~m}$ ，可以看出在相同周期的情况下，随着人射波波 高的增加，越过礁坪上防浪堤堤顶的平均越浪量逐渐 增大，这与缓坡地形中计算越浪的传统公式变化规律 相一致; 同时可以看出当人射波波高不变时, 人射波周

\section{表 1 实验组次}

Table 1 Experimental conditions

\begin{tabular}{ccc}
\hline & 模型值 & 原型值 \\
\hline 防浪堤与礁缘之间距离 $S(\mathrm{~m})$ & $5,10,15,20$ & $75,150,225,300$ \\
$H_{\mathrm{i}}(\mathrm{m})$ & $0.3,0.4,0.5,0.6,0.7,0.8$ & $4.5,6,7.5,9,10.5,12$ \\
$T(\mathrm{~s})$ & $3,3.5,4,4.5$ & $11.62,13.56,15.49,17.43$ \\
$Z_{0}(\mathrm{~m})$ & 5 & 75 \\
礁坪水深 $h(\mathrm{~m})$ & $0,0.1,0.2$ & $0,1.5,3$ \\
礁缘水深 $h_{\mathrm{e}}(\mathrm{m})$ & $0.2,0.3,0.4$ & $3,4.5,6$ \\
干舷高度 $R_{\mathrm{c}}(\mathrm{m})$ & $0.6,0.5,0.4$ & $9,7.5,6$ \\
深水波长 $L_{0}(\mathrm{~m})$ & $14.04,19.11,24.96,31.59$ & $210.6,286.65,374.4,473.85$ \\
\hline
\end{tabular}




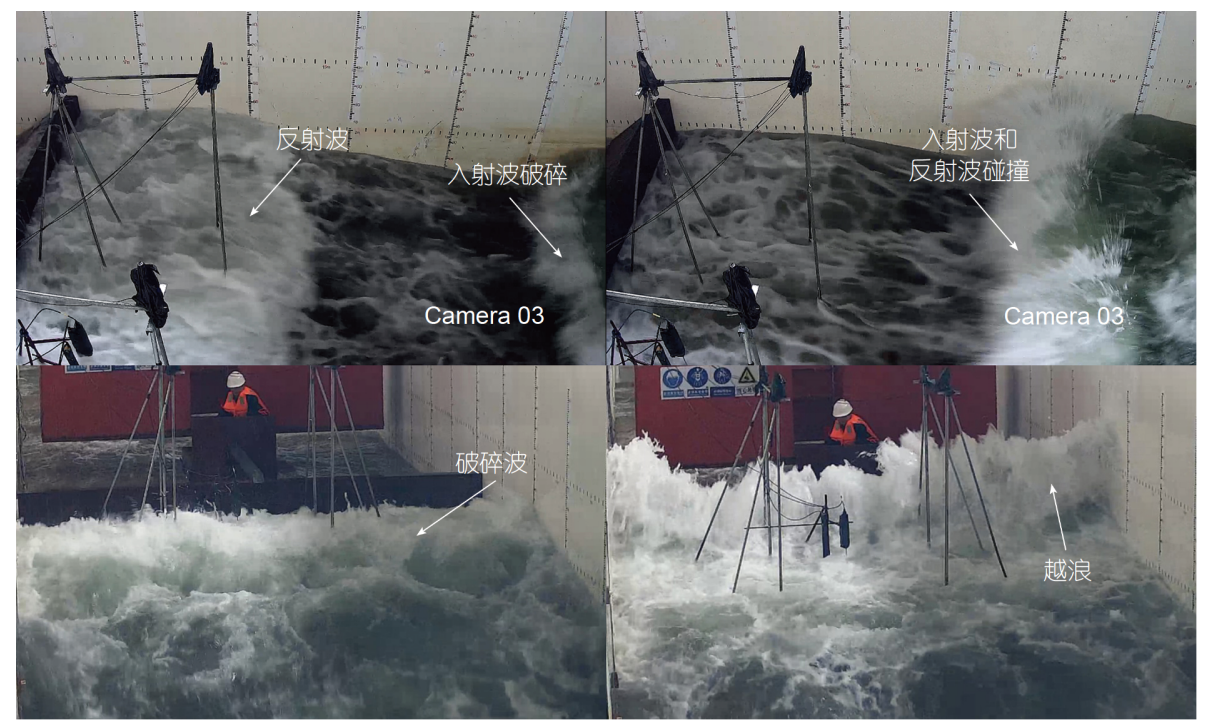

图 4 (网络版彩色) $H_{\mathrm{i}}=9 \mathrm{~m}, T=13.56 \mathrm{~s}, S=75 \mathrm{~m}$ 时波浪的传播及越浪现象

Figure 4 (Color online) Wave propagation and overtopping phenomenon. $S=75 \mathrm{~m}, H_{\mathrm{i}}=9 \mathrm{~m}, T=13.56 \mathrm{~s}$
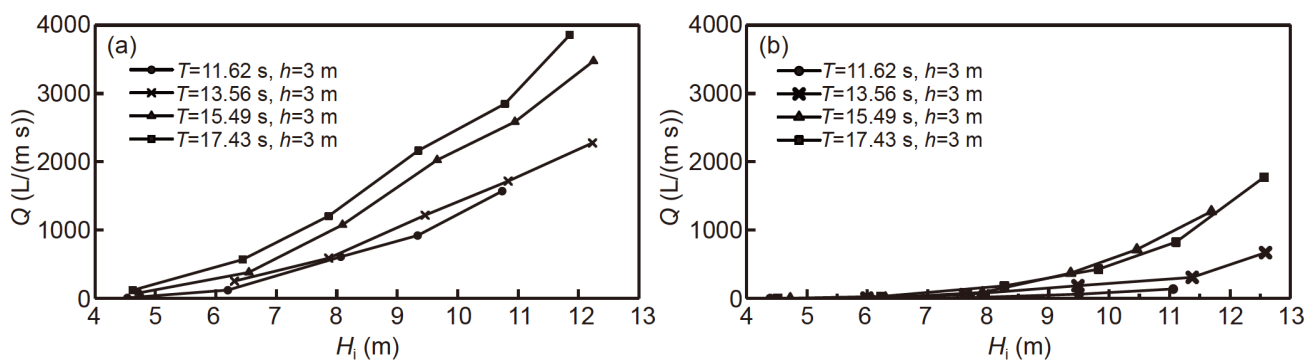

图 $5 S=75 \mathrm{~m}$ 时, 不同周期下的平均越浪量. (a) 礁坪水深 $h=3 \mathrm{~m}$; (b) 礁坪水深 $h=0 \mathrm{~m}$

Figure 5 The effect of different period on the mean overtopping discharge. (a) $S=75 \mathrm{~m}, h=3 \mathrm{~m}$; (b) $S=75 \mathrm{~m}, h=0 \mathrm{~m}$

期增大, 平均越浪量也相应增大. 但当防浪堤堤前水深 为 $0 \mathrm{~m}$ 时, 从图 5 中可以看出当周期相差较小时, 在相同 的人射波波高下, 平均越浪量的差别也在逐渐减小, 所 以当防浪堤堤前水深减少时，周期对越浪量的影响也 在逐渐减小.

\section{3 水深对越浪量的影响}

图6为防浪堤距离礁缘 $75 \mathrm{~m}$ 时不同周期条件下，越 浪量与防浪堤堤前水深和人射波高的关系，可以发现， 随着防浪堤堤前水深的减小, 越浪量显著减小. 堤前的 水深越深, 相应的防浪堤干舷高度越小, 平均越浪量也 就越大.

\section{4 防浪堤与礁缘的距离对平均越浪量的影响}

如图7所示, 当堤前水深 $h=3 \mathrm{~m}$, 人射波周期 $T$ $=11.62 \mathrm{~s}, S=75 \mathrm{~m}$ 时的平均越浪量明显要大于其他距离
时的平均越浪量，并且在相同的人射波波高下，当 $S$ $=300 \mathrm{~m}$ 时的平均越浪量明显减少; 同样如图7中 $h=3 \mathrm{~m}$, $T=17.43,15.49$ 和 $13.56 \mathrm{~s}$ 所示, 整体规律与上述相一致, 即防浪堤与礁缘距离越长，相同波况下的平均越浪量 就越小, 但是会出现在距离 $S$ 的增大过程中, $S=225 \mathrm{~m}$ 时 会有个别点的平均越浪量相较 $S=150 \mathrm{~m}$ 时的平均越浪 量有略微增加的现象出现. 因为当 $S=225 \mathrm{~m}$ 时，长周期 下的波浪在到达越浪量迅速增大的波高临界点前，会 造成回流受阻，堤前雍水增大，导致平均越浪量增加， 如图7中 $T=13.56 \mathrm{~s}, H_{\mathrm{i}}=6.3,7.8$ 和9.5 m; $T=15.49 \mathrm{~s}$, $H_{\mathrm{i}}=6.3$ 和 $8.1 \mathrm{~m} ; T=17.43 \mathrm{~s}, H_{\mathrm{i}}=6.3,7.8,9.4$ 和 $10.8 \mathrm{~m}$ 时, $S=225 \mathrm{~m}$ 的平均越浪量要略微大于同波高下 $S=150 \mathrm{~m}$ 时 的平均越浪量.

\section{5 波陡对无量纲平均越浪量的影响}

如图8所示，当礁坪水深 $h=3 \mathrm{~m}$ (或 $h=0 \mathrm{~m}) 、$ 距离 $S=$ 

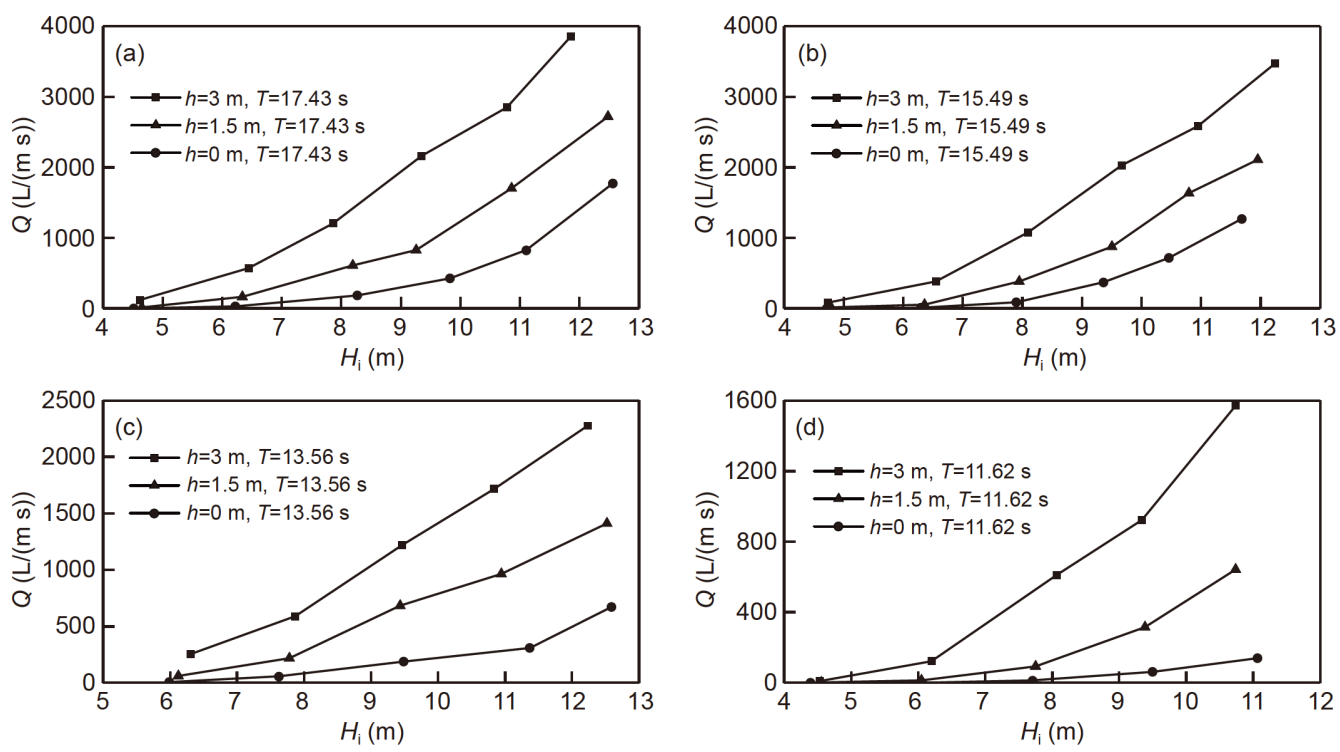

图 $6 S=75 \mathrm{~m}$ 时, 不同水深下的平均越浪量. (a) $T=17.43 \mathrm{~s}$; (b) $T=15.49 \mathrm{~s}$; (c) $T=13.56 \mathrm{~s}$; (d) $T=11.62 \mathrm{~s}$

Figure 6 The effect of different depth of water on the mean overtopping discharge for given $S=75 \mathrm{~m}$. (a) $T=17.43 \mathrm{~s}$; (b) $T=15.49 \mathrm{~s}$; (c) $T=13.56 \mathrm{~s}$; (d) $T=11.62 \mathrm{~s}$
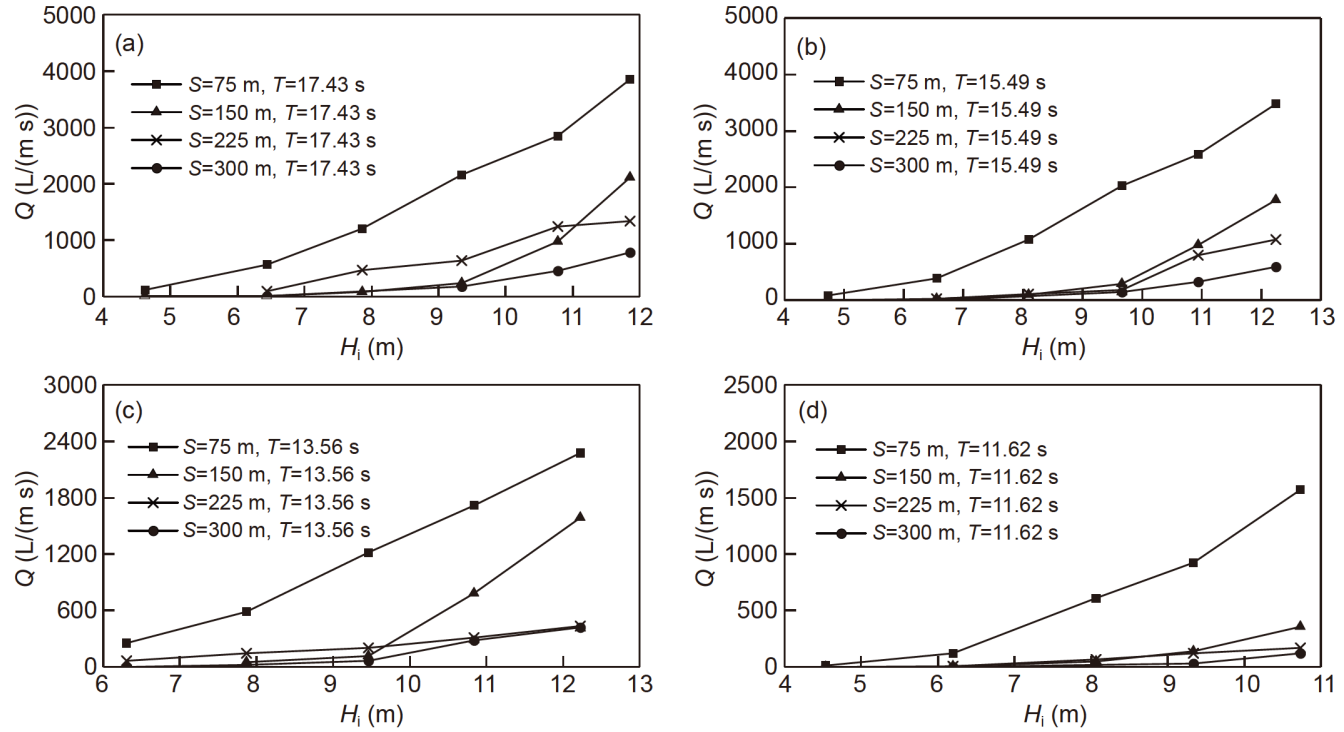

图 $7 h=3 \mathrm{~m}$ 时, 不同距离下的平均越浪量. (a) $T=17.43 \mathrm{~s}$; (b) $T=15.49 \mathrm{~s}$; (c) $T=13.56 \mathrm{~s}$; (d) $T=11.62 \mathrm{~s}$

Figure 7 The effect of different distances on the mean overtopping discharge for given $h=3 \mathrm{~m}$. (a) $T=17.43 \mathrm{~s}$; (b) $T=15.49 \mathrm{~s}$; (c) $T=13.56 \mathrm{~s}$; (d) $T=$ $11.62 \mathrm{~s}$

$75 \mathrm{~m}$ 时，在不同的人射波情况下，无量纲平均越浪量 (即 $q=Q / \sqrt{g H_{\mathrm{i}}^{3}}$ ) 都表现出随着波陡的增大而减小的 规律。这是因为波陡代表着人射波在礁缘处破碎的情 况，在波高相同的情况下，随着波陡越大，人射波在礁 缘处的破碎程度就更加剧烈, 能量耗散的多, 到达防浪 堤时的能量少, 无量纲平均越浪量就越小; 而当水深减 小时, 波浪的破碎也同样变得更加剧烈, 能量耗散的更
多, 无量纲平均越浪量越小.

\section{6 相对干舷高度对无量纲平均越浪量的影响}

如图9所示，防浪堤与礁缘之间的距离 $S=75 \mathrm{~m}$ 时, 当 $R_{\mathrm{c}} / H_{\mathrm{i}}>1.4$ 时, 无量纲平均越浪量 $q\left(q=Q / \sqrt{g H_{\mathrm{i}}^{3}}\right)$ 值基本为 0 ; 在 $1<R_{\mathrm{c}} / H_{\mathrm{i}} \leq 1.4$ 的区间内 $q$ 值随 $R_{\mathrm{c}}$ 的减小 而缓慢增加; 而在 $0<R_{\mathrm{c}} / H_{\mathrm{i}} \leq 1$ 区间内, $q$ 值随 $R_{\mathrm{c}}$ 的减小 


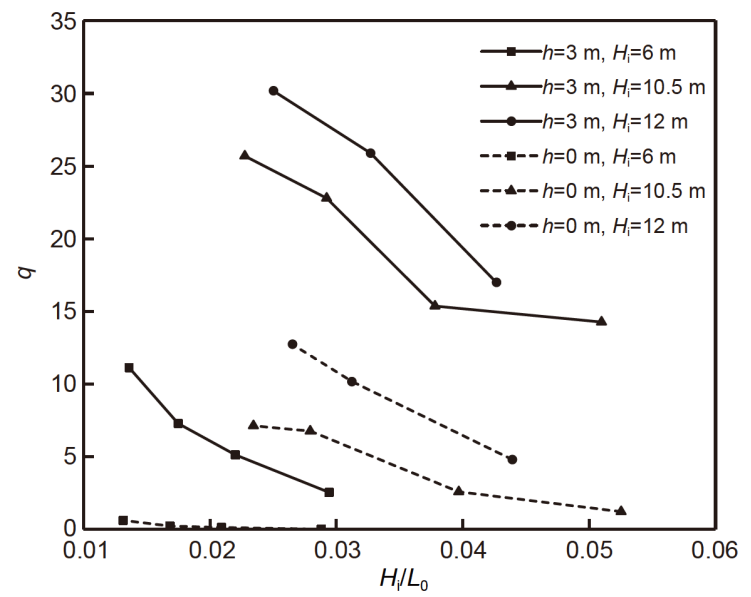

图 $8 S=75 \mathrm{~m}$ 时波陡对无量纲平均越浪量的影响

Figure 8 The effect of the wave steepness on the dimensionless mean overtopping discharge $(S=75 \mathrm{~m})$

而显著增加, 并呈指数型增加的趋势. 采用指数函数拟

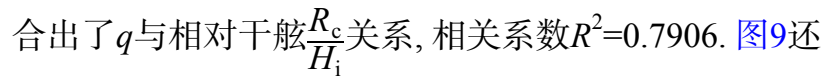
给出了不同周期下 $q$ 与 $\frac{R_{\mathrm{c}}}{H_{\mathrm{i}}}$ 的关系, 可以看出, 周期较大 时 $q$ 值整体偏上, 因此需考虑周期对越浪的影响.

将周期进行无量纲化, 消除周期 $T$ 对 $q$ 值的影响, $H_{\mathrm{i}} / g T^{2}$ 为无量纲化周期, $q_{T}$ 为考虑了周期的无量纲平 均越浪量(即 $q_{T}=Q / \sqrt{g H_{\mathrm{i}}^{3}} * H_{\mathrm{i}} / g T^{2}$ ). 如图10所示, 在 相同的距离 $S$ 下, $q_{T}$ 值随着 $R_{\mathrm{c}} / H_{\mathrm{i}}$ 的减小也同样呈现出 指数型增加趋势, 采用指数函数拟合出了 $q_{T}$ 与相对干 舷 $\frac{R_{\mathrm{c}}}{H_{\mathrm{i}}}$ 关系, 相关系数 $R^{2}=0.4451$. 图10也给出了不同距 离下 $q_{T}$ 与 $\frac{R_{\mathrm{c}}}{H_{\mathrm{i}}}$ 的关系, 可以看出, 不同距离的 $q_{T}$ 值变化趋 势有明显差异, 距离较近的 $q_{T}$ 值整体偏上, 说明除周期 外, 还需考虑距离对越浪量的影响.

将防浪堤与礁缘之间的距离 $S$ 进行无量纲化，消除 $S$ 的不同对 $q_{T}$ 值的影响. 因为礁坪水深存在等于 0 的情 况, 导致使用礁坪水深对距离进行无量纲化时会使 $q_{T}$ 值趋于无穷大，所以采用礁缘水深 $h_{\mathrm{e}}$ 来替代礁坪水深 $h$ 对距离 $S$ 进行无量纲化, 即:

$q_{T, S, h}=\frac{Q}{\sqrt{\mathrm{g} H_{\mathrm{i}}^{3}}} \frac{H_{\mathrm{i}}}{g T^{2}} \frac{S}{T \sqrt{g h_{\mathrm{e}}}}$,

式中, $q_{T, S, h}$ 为考虑了周期、距离和水深的无量纲平均越 浪量; $H_{\mathrm{i}} / g T^{2}$ 为无量纲化周期; $S / T \sqrt{g h_{\mathrm{e}}}$ 为无量纲化距

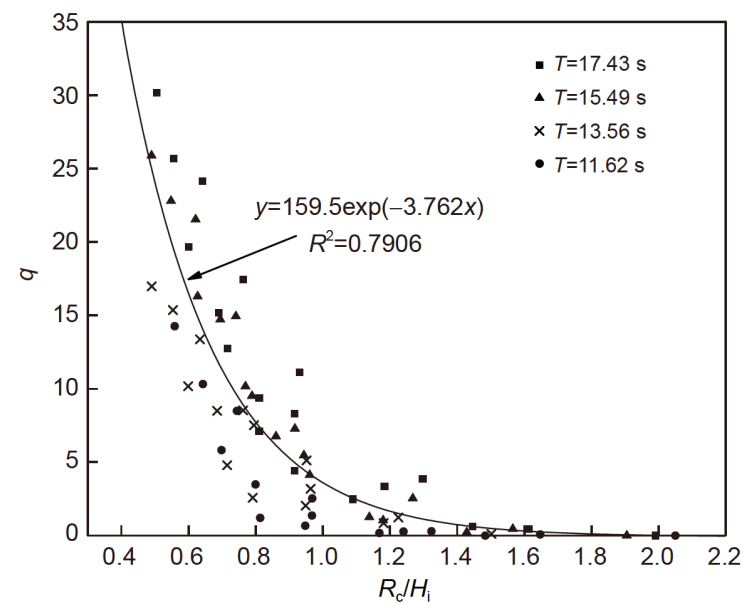

图 $9 S=75 \mathrm{~m}$ 时相对干舫高度对无量纲平均越浪量的影响 Figure 9 The effect of the relative freeboard height on the dimensionless mean overtopping discharge $(S=75 \mathrm{~m})$

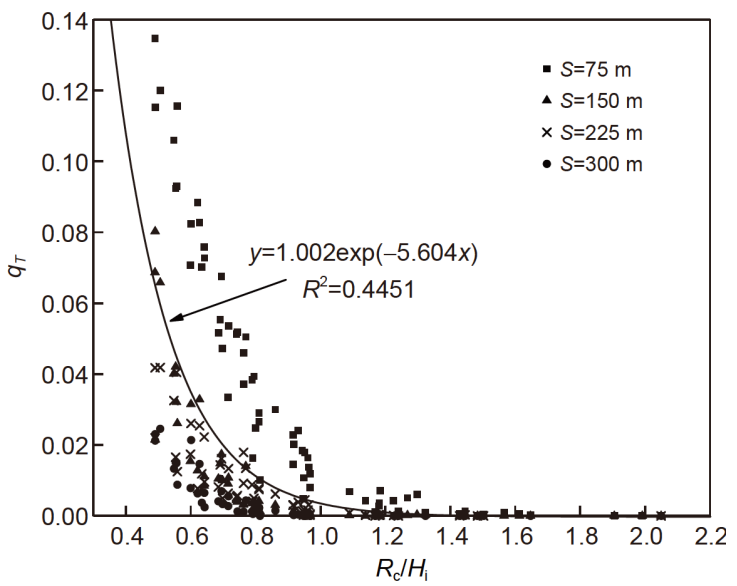

图 10 相对干舷高度对考虑了周期的无量纲平均越浪量的影响 Figure 10 The effect of the relative freeboard height on the dimensionless mean overtopping discharge considering period

离, $h_{\mathrm{e}}$ 为礁缘水深 $\left(h_{\mathrm{e}}=3+h\right)$.

如图11所示，将周期 $T$ 、距离 $S$ 和水深 $h$ 都考虑后, 可以看到当 $R_{\mathrm{c}} / H_{\mathrm{i}}>1.4$ 时, $q_{T, S, h}$ 基本为 0 ; 当 $1<R_{\mathrm{c}} / H_{\mathrm{i}} \leqslant 1.4$ 时, $q_{T, S, h}$ 开始随着 $R_{\mathrm{c}} / H_{\mathrm{i}}$ 的减小逐渐增加; 当 $0.4<R_{\mathrm{c}} / H_{\mathrm{i}} \leqslant 1$ 时, $q_{T, S, h}$ 随着 $R_{\mathrm{c}} / H_{\mathrm{i}}$ 的减小大幅度增加. 采用最小二乘法 对图11中的数据点进行指数函数拟合, 得到:

$$
\begin{aligned}
q_{T, S, h} & =\frac{Q}{\sqrt{\mathrm{g} H_{\mathrm{i}}^{3}}} \frac{H_{\mathrm{i}}}{g T^{2}} \frac{S}{T \sqrt{g h_{\mathrm{e}}}} \\
& =1.279 \exp \left(-5.791 \frac{R_{\mathrm{c}}}{H_{\mathrm{i}}}\right) .
\end{aligned}
$$

公式(5)的相关系数 $R^{2}=0.7574$, 图 11 中虚线为数据的 $95 \%$ 置信区间，这是考虑了周期、礁坪水深和距离后， 


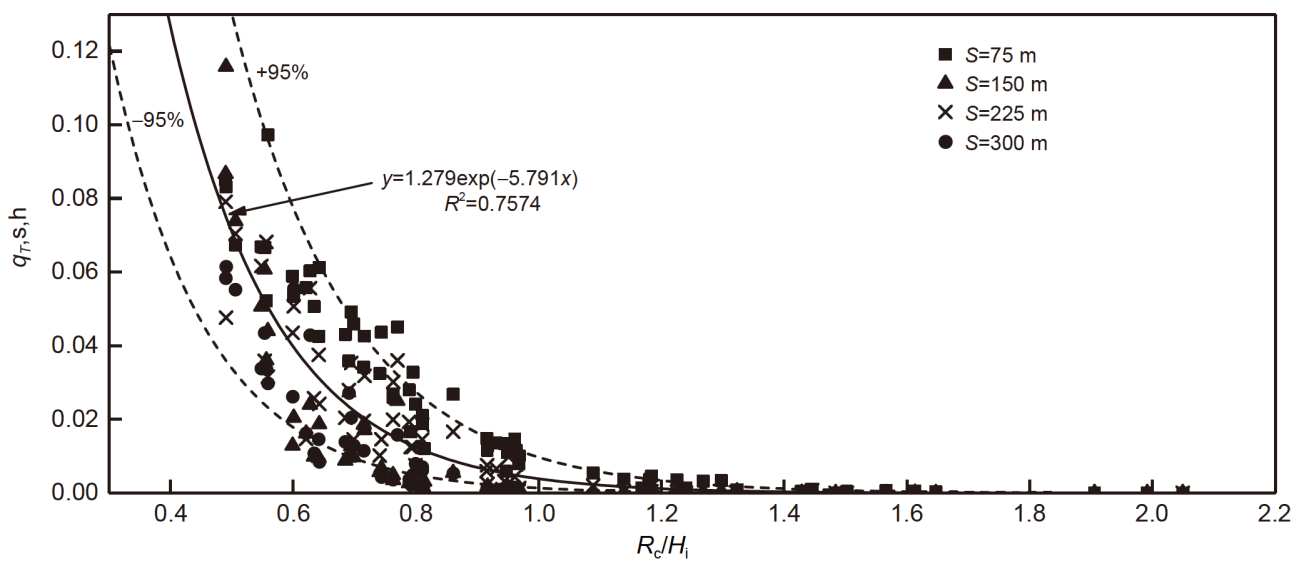

图 11 相对干舷高度对考虑了距离、周期和水深的无量纲平均越浪量的影响

Figure 11 The effect of the relative freeboard height on the dimensionless mean overtopping discharge considering distance, period and water depth

基于本实验数据拟合出的珊瑚礁地形上直立堤的越浪 量估算公式. 需要指出的是, 本次试验礁盘采用不透水 的光滑混凝土面模拟，实际礁盘上有较大的孔隙结构, 波浪在礁盘上传播的过程会受到底摩阻的影响，使得 防浪堤的越浪量有所减小.

\section{4 结论}

采用1:15的模型比尺, 在交通运输部天津水运工程 科学研究院的大比尺波浪水槽进行实验，对规则波在 筑堤珊瑚礁上的越浪规律进行了研究，重点分析了人 射波波高、周期、礁坪水深和防浪堤与礁缘之间距离 的不同对越浪的影响，又对平均越浪量进行了无量纲 分析, 得到的主要结论有:

(1) 波浪在筑堤珊瑚礁上传播时, 在礁缘处发生破 碎, 随后在礁坪上发生碰撞, 碰撞次数随着距离的增加 和周期的减小而增多.

（2）在筑堤珊瑚礁上，当人射波周期相同时，随着
人射波波高的增加, 平均越浪量增大, 与缓坡地形中计 算越浪的传统公式的变化规律相一致; 当人射波波高 不变时，周期增大，平均越浪量也相应增大，但当水深 越来越浅时, 周期对越浪的影响也逐渐减小; 当人射波 波高和周期不变时, 随着礁坪水深的减小, 越浪量明显 减少. 而在波高相同的情况下，波陡越大，人射波在礁 缘处的破碎程度就更加剧烈, 越浪量也越小.

(3) 防浪堤与礁缘之间距离的变化对于越浪的影 响并不是单纯的随着距离增加越浪量一直减少, 当距 离在离礁缘很近的范围处开始逐渐增大时，越浪量随 之明显减小, 但距离增大到 $225 \mathrm{~m}$ 时, 因为回流受阻, 雍 水增加的原因, 越浪量相较于前一个距离会有略微的 增大; 当距离继续增加时, 越浪量会急剧减少.

（4）在无量纲分析中，当相对干舷高度越小时，无 量纲平均越浪量越大，并且在考虑了周期、礁坪水深 和防浪堤与礁缘之间距离后，拟合出基于本实验数据 的珊瑚礁地形上直立堤的越浪量估算公式.

\section{参考文献}

1 Xu C D, Feng S Z. Divisions of island-reef types and discussion on sustainable development (in Chinese). Coast Eng, 2008, 27: 47-52 [徐承德, 冯 守珍. 岛礁类型划分及可持续发展探讨. 海岸工程, 2008, 27: 47-52]

2 Gourlay M R. Wave transformation on a coral reef. Coast Eng, 1994, 23: 17-42

3 Gourlay M R. Wave set-up on coral reefs. 1. Set-up and wave-generated flow on an idealised two dimensional horizontal reef. Coast Eng, 1996, 34: 161-193

4 Gourlay M R. Wave set-up on coral reefs. 2. Set-up on reefs with various profiles. Coast Eng, 1996, 36: 17-55

5 Jensen M S, Burcharth H F, Brorsen M. Wave energy dissipation of waves breaking on a reef with a steep front slope. In: The International Symposium on Ocean Wave Measurements and Analysis. IAHR Secretariat, 2005

6 Nwogu O, Demirbilek Z. Infragravity wave motions and runup over shallow fringing reefs. J Waterway Port Coast Ocean Eng, 2010, 136: 295-305

7 Fang K Z. Fully nonlinear modeling wave transformation over fringing reefs using shock-capturing Boussinesq model. J Coast Res, 2015, 32: 164-171

8 Yao Y, Yuan W C, Du R C, et al. Experimental study of reef crest's effects on wave transformation and wave-induced setup over fringing reefs (in 
Chinese). J Trop Oceanogr, 2015, 34: 19-25 [姚宇, 袁万成, 杜睿超, 等. 岸礁礁冠对波浪传播变形及增水影响的实验研究. 热带海洋学报, 2015, 34: 19-25]

9 Yao Y, Du R C, Jiang C B, et al. Experimental study of the effect of reef-crest width on wave-induced set-up over the reef flat (in Chinese). Mar Sci Bull, 2017, 36: 340-347 [姚宇, 杜睿超, 蒋昌波, 等. 礁冠宽度对珊瑚礁坪波浪增水影响的实验研究. 海洋通报, 2017, 36: 340-347]

10 Chen S G, Zhang H Q, Chen H B, et al. Experimental study of irregular wave transformation on reefs with seawalls in large wave flume (in Chinese). Mar Sci Bull, 2018, 5: 576-582 [陈松贵, 张华庆, 陈汉宝, 等. 不规则波在筑堤珊瑚礁上传播的大水槽实验研究. 海洋通报, 2018, 5: 576-582]

11 Ministry of Transport of China. JTS145-2015 Hydrographic Code for Ports and Waterways (in Chinese). Beijing: China Communications Press, 2015[中华人民共和国交通运输部. A-JTS145-2015, 港口与航道水文规范. 北京: 人民交通出版社出版, 2015]

12 Wang H, Zhou J B, Zhang J C. The Physical Model Report of Overtopping Study. Technical Report, Nanjing Hydraulic Research Institute, 1992 [王红, 周家宝, 章家昌. 越浪量模型试验研究报告. 南京水利科学研究院, 1992]

13 Wang H, Zhou J B. Estimating of irregular wave overtopping quantities on single sloping (in Chinese). J Nanjing Hydr Res Inst, 1996, 28: 58-63 [王红, 周家宝. 单坡堤上不规则波越浪量的估算. 水利水运工程学报, 1996, 28: 58-63]

14 Li X L, Yu Y X, Zhao F Y, et al. Experimental study on mean overtopping discharge of sloping seawall under oblique and multidirectional irregular waves (in Chinese). Acta Oceanol Sin, 2007, 29: 139-149 [李晓亮, 俞聿修, 赵凤亚, 等. 斜向和多向不规则波在斜坡堤上的平均越浪量的试验 研究. 海洋学报, 2007, 29: 139-149]

15 Yu Y X, Li X L. Experiment study of overtopping performance of sloping seawall under oblique and multi-directional irregular waves. Coast Eng J, 2007, 49: 77-101

16 Owen M W. Design of Seawalls Allowing for Wave Overtopping. Technical Report, Hydraulic Research Wallingford, UK, 1980

17 Owen M W. Overtopping of sea defences. In: International Conference on the Hydraulic Modelling of Civil Engineering Structures, Coventry, 1982

18 Owen M W, Steele A A J. Effectiveness of Recurved Wave Return Walls. Technical Report, Hydraulic Research Wallingford, UK, 1993

19 Van der Meer J W, Janssen J P. Wave Run-up and Wave Overtopping at Dikes and Revetments. Technical Report, Delft Hydraulics, 1994

20 Van der Meer J W, Jentsje W. Wave run-up and overtopping. In: Pilarczyk K W, ed. Dikes and Revetments: Design, Maintenance and Safety Assessment. Rotterdam: AA Balkema, 1998. 145-159

21 De Waal J P, Van der Meer J W. Wave runup and overtopping on coastal structures. In: Coastal Engineering Proceedings, 1992, 23: 346-355

22 Franco L, De Gerloni M, Van der Meer J W. Wave overtopping on vertical and composite breakwaters. Coast Eng, 1994: 1030-1045

23 Goda Y. Random Sseas and Design of Maritime Structures. Singapore: World Scientific Publishing Company, 2010

24 Ward D L, Ahrens J P. Overtopping Rates for Seawalls. Technical Report, Coastal Engineering Research Center, USA, 1992

25 Yu Y X. Comparison of methods for calculating mean wave overtopping on sloping seawall (in Chinese). Port Eng Technol, 2011, 48: 1-4 [俞聿 修. 斜坡堤上平均越浪量计算方法的比较. 港工技术, 2011, 48: 1-4]

26 Van der Meer J W, Allsop W, Bruce T, et al. Manual on wave EurOtop, overtopping of sea defences and related structures. www.overtoppingmanual.com. 2016

27 Van der Meer J W, Bruce T. New physical insights and design formulas on wave overtopping at sloping and vertical structures. J Waterway Port Coast Ocean Eng, 2013, 140: 4010-4025

28 Sun H, Wang Y, Peng J. Hilbert transform applied to separation of waves. China Ocean Eng, 2002, 16: 239-248 


\title{
Experiment on wave overtopping of a vertical seawall on coral reefs in large wave flume
}

\author{
Songgui Chen ${ }^{1,2}$, Zeming Wang ${ }^{1}$, Chi Zhang ${ }^{1}$, Hanbao Chen $^{2} \&$ Jinhai Zheng ${ }^{\text {* }}$ \\ ${ }^{1}$ College of Harbour, Coastal and Offshore Engineering, Hohai University, Nanjing 210024, China; \\ ${ }^{2}$ Tianjin Research Institute for Water Transport Engineering, Ministry of Transport, Tianjin 300456, China \\ * Corresponding author, E-mail: jhzheng@hhu.edu.cn
}

Coral reefs are widely distributed in the South China Sea, and its topography is different from the gentle slope of the coastal continental shelf, which has a great impact on wave propagation and deformation. At the same time, reefs are located in a harsh marine environment, so these factors having a profound effect on the stability of the backfilled sand island and the effective operation of other ancillary facilities. Seawall is an important protective structure in the protection works of reefs, and the wave overtopping of seawall plays a decisive role in the engineering safety of reefs. At present, there are few studies on the wave overtopping of reefs around the world, and the existing formula for calculating wave overtopping discharges over seawall on gentle slope terrain is not applicable to reefs terrain, so detailed research on wave overtopping of a vertical seawall on coral reefs is needed.

A series of experiments are carried out in the Large Wave Flume (LWF) of Tianjin Research Institute of Water Transport Engineering (TIWTE), which is $456 \mathrm{~m}$ long, $12 \mathrm{~m}$ deep and $5 \mathrm{~m}$ wide. The maximum wave height generated by LWF is $3.5 \mathrm{~m}$, and the wave period range is from 2 to $10 \mathrm{~s}$. The model layout includes 3 parts: Deep-water zone, steep slope zone and platform zone. The depth of the deep-water zone is $5 \mathrm{~m}$. The front slope is divided into 3 sections with slope 1:1, 1:4 and 1:15. The steep slope toe is $330 \mathrm{~m}$ away from the wave generator. The strongly non-linear physical process of wave transmission and breaking can be reproduced by this physical model.

Based on Froude similarity criterion and a 1:15 scale model, the propagation and deformation process of regular waves on reef-top with seawall is analyzed. The effects of wave height, wave period, water depth and the distance between seawall and reef-edge on the mean overtopping discharge are studied. The results show that the mean overtopping discharge increases significantly with increasing of wave height and period, while it decreases with decreasing of water depth. However, the mean overtopping discharge is not the monotone function with distance. Mostly the mean overtopping discharge decreases with increasing distance. When wave period is longer than $13.56 \mathrm{~s}$, the mean overtopping discharge decreases firstly, then increases a little, finally decreases with increasing distance. The dimensionless mean wave overtopping discharge increases as the wave steepness decreases for given wave height. The dimensionless mean wave overtopping discharge is found to be functions of relative freeboard height, the dimensionless mean wave overtopping discharge decreases as relative freeboard height increases for given wave conditions. On the basis of the experimental data, a formula considering the effects of wave height, wave period, water depth and the distance between seawall and reef-edge on the wave overtopping, is presented to estimate the mean wave overtopping discharge of a vertical seawall on coral reefs.

coral reefs, large wave flume, vertical seawall, overtopping formula

doi: 10.1360/N972018-01195 